\title{
Forest disease records on eastern white pine in Atlantic Canada: 1950 to 1996
}

\author{
by K.J. Harrison ${ }^{1}$
}

\begin{abstract}
Between 1936 and 1996, the Forest Insect and Disease Survey (FIDS) of the Canadian Forest Service of Natural Resources Canada surveyed eastern white pine (Pinus strobus L.) throughout Atlantic Canada. During those years, FIDS reported its insect and disease findings in a wide variety of regional and national reports and in the scientific literature. The National Forest Health Database contains these electronic records and indicates the distribution and relative importance of forest diseases and fungi for many tree species in Atlantic Canada. This paper is a frequency analysis of the fungal diseases recorded from the Atlantic provinces in the National Forest Health Database and reported in the various Maritime, Newfoundland and national FIDS reports. The significant eastern white pine diseases (e.g., white pine blister rust Cronartium ribicola J.C. Fisch.) that are established in Atlantic Canada as well as other diseases that are found elsewhere in Canada, but not yet in the Atlantic provinces are discussed. Occurrence data for 40 of the less frequently collected fungal species are presented in a summary table.
\end{abstract}

Key words: white pine blister rust, Cronartium ribicola, eastern white pine, Pinus strobus, Scleroderris canker, Gremmeniella abietina, Annosus root rot, Heterobasidion annosum, white pine root decline, Leptographium procerum, needle cast, Lophodermium pinastri, brown felt fungus, Septobasidium pinicola, Atlantic Canada, forest disease

\section{RÉSUMÉ}

De 1936 à 1966, le Relevé des insectes et des maladies des arbres effectué par le Service canadien des forêts du Ministère des Ressources naturelles du Canada comprenait le pin blanc de l'Est (Pinus strobus L.) de toute la région de l'Atlantique. Au cours de ces années, le Relevé a fait état des insectes et des maladies répertoriés dans de nombreux rapports régionaux et nationaux ainsi que dans la littérature scientifique. La Base nationale de données sur la santé des forêts contient ces fichiers électroniques et illustre la distribution et l'importance relative des maladies et des champignons du milieu forestier pour plusieurs espèces de la région de l'Atlantique. Cet article représente une analyse de fréquence des maladies fongiques identifiées dans les Provinces atlantiques selon la Base de données sur la santé des forêts et diffusées dans les différents rapports produits dans les Maritimes, à Terre-Neuve et à léchelle nationale. Les plus importantes maladies du pin blanc de l'Est (par ex., la rouille vésiculeuse du pin blanc - Cronartium ribicola J.C. Fisch.) qui sont bien établies dans la région de l'Atlantique ainsi que les autres maladies retrouvées ailleurs au Canada, mais pas encore dans les Provinces atlantiques font l'objet d'une discussion. Les données d’occurrence de 40 espèces fongiques parmi les moins fréquentes sont présentées sous la forme d'un tableau synthèse.

Mots clés : rouille vésiculeuse du pin blanc, Cronartium ribicola, pin blanc de l'Est, Pinus strobus, chancre scléroderrien, Gremmeniella abietina, maladie du rond, Heterobasidion annosum, dépérissement des racines du pin blanc, Leptographium procerum, rouge du pin noir, Lophodermium pinastri, feutrage brun, Septobasidium pinicola, région de l'Atlantique, maladie forestière

\footnotetext{
${ }^{1}$ Natural Resources Canada, Canadian Forest Service - Atlantic Forestry Centre, P.O. Box 4000, Fredericton, New Brunswick E3B 5P7. Email: Ken.Harrison@nrcan.gc.ca
} 


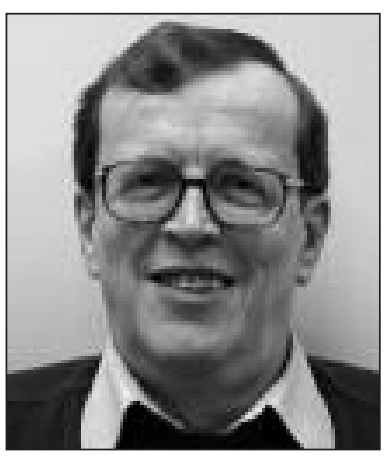

K.J. Harrison

\section{Introduction}

There is renewed interest in eastern white pine (Pinus strobus L.) in Atlantic Canada. A primary concern for foresters is the presence of disease organisms that may damage or endanger the resource. Throughout its 60-year history, the former Forest Insect and Disease Survey (1936 to 1996) of the Canadian Forest Service of Natural Resources Canada collected biological data on insects, fungi and nematodes associated with forest and urban trees across Canada. These data are recorded electronically in the National Forest Health Database (NFHDB). The initial effort to collect biological survey data for forest diseases and fungi was begun by the Forest Disease Survey about 1950, but the majority of the fungal records were collected between 1953 and 1996. Eastern white pine was one of the tree species examined during those years. In 1964, the Forest Disease Survey was merged with the Forest Insect Survey to become the Forest Insect and Disease Survey. The fungal records from eastern white pine in the Atlantic provinces are examined in this paper. Only a few of these fungi cause tree mortality or significant growth loss. These data support the conclusion by Hodges (1985) that: "no one disease poses a serious threat to continued culture of this important tree species." Most of these fungal records are simple wood decays or saprophytes growing on dead tissue.

\section{Plant Quarantine Diseases Present in Atlantic Canada \\ White pine blister rust (Cronartium ribicola J.C. Fischer)}

The introduction of the white pine blister rust fungus into both the eastern and western parts of North America in the early $20^{\text {th }}$ century, and its subsequent spread and impact, is well documented elsewhere (e.g., Sinclair and Lyon 2005). There are numerous online links to publications that provide silvicultural guidelines for eastern white pine and white pine blister rust management. The disease is present throughout the Atlantic provinces wherever eastern white pine and the disease's alternate hosts (Ribes spp. - currants and gooseberries) occur. Of the diseases and fungi recorded from eastern white pine in the NFHDB, white pine blister rust accounts for 316 of the total of 871 fungal records (36.3\% of all records). It remains the most significant reported disease of eastern white pine in the Atlantic provinces.

\section{European and North American races of Scleroderris canker} [Gremmeniella abietina [Lagerb.] Morelet]

The introduced European race of Scleroderris canker is known to kill large, pole-sized pine trees whereas the native North American race can attack and kill young plantation trees up to a height of $2 \mathrm{~m}$. There are occasional records of the North American race of Scleroderris on eastern white pine, but it is usually a disease of hard pines (e.g., red pine - Pinus resinosa Ait., jack pine- Pinus banksiana Lamb.). The distribution of the European race of Scleroderris in Atlantic Canada is very different from the introduction and spread of white pine blister rust. Scleroderris canker is not generally distributed and so it is difficult to make a single statement that would be accurate for all 4 Atlantic provinces.

The separation of Scleroderris canker into European and North American races has been discussed elsewhere (e.g., Laflamme et al. 1998). Publications produced in the Maritime provinces before 1989 (e.g., Magasi 1988) reported results of the older serological testing method that often gave contradictory results. These reports should not be presumed to be accurate until compared with Laflamme et al. (1998), Hurley et al. (2000) and Harrison et al. (2000). To date, it appears that only the North American race of Scleroderris canker occurs occasionally on eastern white pine.

\section{Significant Diseases Not Present in Atlantic Canada} Annosus root and butt rot (Heterobasidion annosum [Fr.:Fr.] Bref.]]

Unlike in western and central Canada, Annosus root and butt rot has never been recorded in the Atlantic provinces. Annosus root and butt rot is transcontinental from British Columbia to western Quebec but it has never been found east of Quebec. The disease is found on many conifer genera, including eastern white pine. Sinclair and Lyon (2005) state that this very destructive rot is: "Not reported from the boreal forests of central and eastern Canada." There is only one published report of Annosus root and butt rot from Colchester County in Nova Scotia (Sommers 1880). This sole anecdotal report is repeated in the later literature (e.g., Gourley 1983) but it has never been confirmed with a specimen or any authoritative collections in over a century of subsequent searches.

White pine root decline (Leptographium procerum [W.B. Kendr.] M.J. Wingf., formerly known as Verticicladiella procera] This is a fungal associate of numerous native and non-indigenous bark beetles and weevils is widely distributed in "Canada, Europe, New Zealand, U.S.A., South Africa" according to Jacobs and Wingfield (2001). It was recently isolated from Scots pine infested with the introduced pine shoot beetle [Tomicus piniperda [(L.]) in Ontario and reported by Hausner et al. (2005). Before this, the white pine root decline fungus had been only reported once each from Ontario and Quebec. It has not been reported from Atlantic Canada to date.

Fungal associate of Sirex wood wasp (Sirex noctilio Fabricius), Amylostereum areolatum (Fr.) Boidin.

The insect vector, Sirex noctilio, has only recently been found in Ontario after the initial North American finds in upper New York State in 2005. Currently, the insect is believed to be established in 25 counties in western New York State and 2 counties in neighbouring Pennsylvania. Work is progressing elsewhere to define its distribution in Ontario and Quebec. This insect is known to attack eastern white pine although it does occur more frequently on Scots and other exotic pine species. To date, neither the Sirex wood wasp nor the associated fungus have been reported from Atlantic Canada.

\section{Notes on Other Diseases and Fungi}

Only 7 fungi have been recorded more than 9 times in the NFHDB from the Atlantic provinces (Table 1).

A. There are 30 records for the "Brown felt fungus" (Septobasidium pinicola Snell) in the database. Although common on the bark of eastern white pine, this highly specialized 
Table 1. Fungal diseases reported from eastern white pine in Atlantic Canada ( 1950-1996)

Source: National Forest Health Database, Natural Resources Canada, Canadian Forest Service, P.O. Box 4000, Fredericton, N.B. E3B 5P7

\begin{tabular}{|c|c|c|c|c|c|c|}
\hline Scientific name & $\begin{array}{l}\text { Common } \\
\text { name }\end{array}$ & Origin & Host(s) & $\begin{array}{l}\text { Tree part } \\
\text { affected }\end{array}$ & $\begin{array}{l}\text { Reports in } \\
\text { database }\end{array}$ & $\begin{array}{l}\text { Damage to eastern } \\
\text { white pine }\end{array}$ \\
\hline $\begin{array}{l}\text { Amylocorticium } \\
\text { subsulphureum }\end{array}$ & Rot & Native & Conifers & Wood & 1 & \\
\hline Armillaria mellea & $\begin{array}{l}\text { Shoestring } \\
\text { root rot or } \\
\text { Armillaria } \\
\text { root rot }\end{array}$ & Native & Many & Root and butt & 13 & Rare reports on few trees \\
\hline Atropellis tingens & Atropellis canker & Native & Pinus spp. & Woody parts & 3 & \\
\hline Bifusella linearis & Needle cast & Native & $\begin{array}{l}\text { 5-needle } \\
\text { Pinus spp. }\end{array}$ & Needles & 13 & Foliage \\
\hline Caliciopsis pinea & $\begin{array}{l}\text { Caliciopsis } \\
\text { canker }\end{array}$ & Native & Conifers & Woody parts & 7 & \\
\hline Calocera cornea & Fungus & Native & $\begin{array}{l}\text { Usually } \\
\text { hardwood }\end{array}$ & Dead wood & 1 & \\
\hline Cenangium acicola & Fungus & Native & Pinus spp. & Needles & 4 & \\
\hline Cenangium ferruginosum & Dieback & Native & Pinaceae & $\begin{array}{l}\text { Twigs and } \\
\text { shoots }\end{array}$ & 3 & Saprophyte \\
\hline Coccomyces strobi & Needle fungus & Native & Pinus spp. & Needles & 9 & Foliage \\
\hline $\begin{array}{l}\text { Coniophora (kalmiae) } \\
\text { puteana }\end{array}$ & Rot & Native & Usually conifers & Woody parts & 1 & \\
\hline $\begin{array}{l}\text { Corticium } \\
\text { (Laeticorticium) pini }\end{array}$ & Rot & Native & Pinus spp. & Woody parts & 1 & \\
\hline Cronartium ribicola & $\begin{array}{l}\text { White pine } \\
\text { blister rust }\end{array}$ & Asia, Europe & $\begin{array}{l}\text { 5-needle } \\
\text { Pinus spp. }\end{array}$ & $\begin{array}{l}\text { Stems and } \\
\text { branches }\end{array}$ & 316 & $\begin{array}{l}\text { Widespread and } \\
\text { variable reports }\end{array}$ \\
\hline Cucurbidothis pithyophila & Fungus & Native & Pinus spp. & Twigs & 9 & $\begin{array}{l}\text { Usually associated } \\
\text { with scale insects }\end{array}$ \\
\hline Dacrymyces deliquescens & Jelly fungus & Native & All & Dead wood & 2 & \\
\hline Dermea pinicola & $\begin{array}{l}\text { Canker - } \\
\text { secondary }\end{array}$ & Native & Pinus spp. & Woody parts & 5 & \\
\hline Fomes pinicola & Rot & Native & Usually conifers & Woody parts & 1 & \\
\hline $\begin{array}{l}\text { Fomitopsis (Fomes) } \\
\text { cajanderi }\end{array}$ & Rot & Native & Conifers & Woody parts & 1 & \\
\hline Ganoderma lucidum & Shelf fungus & Native & Conifers & $\begin{array}{l}\text { Dead stems, } \\
\text { stumps }\end{array}$ & 2 & \\
\hline \multicolumn{7}{|l|}{ Gremmeniella abietina } \\
\hline European race & $\begin{array}{l}\text { Scleroderris } \\
\text { canker }\end{array}$ & Europe & All pines & $\begin{array}{l}\text { Twigs and } \\
\text { shoots }\end{array}$ & 0 & $\begin{array}{l}\text { Concern in } \\
\text { Newfoundland }\end{array}$ \\
\hline North American race & $\begin{array}{l}\text { Scleroderris } \\
\text { canker }\end{array}$ & Native & All pines & $\begin{array}{l}\text { Twigs and } \\
\text { shoots }\end{array}$ & 5 & Lower branches in NB \\
\hline Hyphodontia pallidula & Rot & Native & All & Woody parts & 1 & \\
\hline $\begin{array}{l}\text { Hyphodontia (Odontia) } \\
\text { spathulata }\end{array}$ & Rot & Native & All & Woody parts & 1 & \\
\hline Kuehneromyces vernalis & Rot & Native & Conifers & Wood & 2 & \\
\hline Lachnellula agassizii & "Bark fungus" & Native & Conifers & Bark and wood & 12 & On dead bark \\
\hline Lenzites sepiaria & Rot & Native & Usually conifers & Woody parts & 3 & \\
\hline
\end{tabular}


Table 1. Fungal diseases reported from eastern white pine in Atlantic Canada ( 1950-1996) (continued)

Source: National Forest Health Database, Natural Resources Canada, Canadian Forest Service, P.O. Box 4000, Fredericton, N.B. E3B 5P7

\begin{tabular}{|c|c|c|c|c|c|c|}
\hline Scientific name & $\begin{array}{l}\text { Common } \\
\text { name }\end{array}$ & Origin & Host(s) & $\begin{array}{l}\text { Tree part } \\
\text { affected }\end{array}$ & $\begin{array}{l}\text { Reports in } \\
\text { database }\end{array}$ & $\begin{array}{l}\text { Damage to eastern } \\
\text { white pine }\end{array}$ \\
\hline Leucostoma kunzei & Cytospora canker & Native & Conifers & $\begin{array}{l}\text { Twigs and } \\
\text { shoots }\end{array}$ & 4 & \\
\hline Lophodermium nitens & Needle cast & Native & $\begin{array}{l}\text { 5-needle } \\
\text { Pinus spp. }\end{array}$ & Needles & 7 & Foliage \\
\hline Lophodermium pinastri & Needle cast & Native & Conifers & Foliage & 22 & Nursery stock \\
\hline Meloderma desmazierii & Needle cast & Native & Pines & Needles & 11 & Foliage \\
\hline Mycosphaerella sp. & Needle blight & Native & Pines & Needles & 1 & \\
\hline Peniophora aspera & Rot & Native & All & Woody parts & 1 & \\
\hline Peniophora burtii & Rot & Native & All & Fallen limbs & 1 & \\
\hline $\begin{array}{l}\text { Phaeolus (Polyporus) } \\
\text { schweinitzii }\end{array}$ & Rot & Native & Conifers & Butt rot & 2 & \\
\hline Phellinus (Fomes) pini & Heart rot & Native & Conifers & Woody parts & 2 & \\
\hline $\begin{array}{l}\text { Polyporus (Trichaptum) } \\
\text { abietinus }\end{array}$ & Saprot & Native & Conifers & Wood & 9 & \\
\hline Poria pannocincta & Rot & Native & $\begin{array}{l}\text { Usually } \\
\text { hardwood }\end{array}$ & Wood & 1 & \\
\hline Scoleconectria cucurbitula & $\begin{array}{l}\text { Canker - } \\
\text { secondary }\end{array}$ & Native & Conifers & $\begin{array}{l}\text { Twigs and } \\
\text { branches }\end{array}$ & 12 & \\
\hline Septobasidium pinicola & $\begin{array}{l}\text { Brown felt } \\
\text { fungus }\end{array}$ & Native & Scale insects & $\begin{array}{l}\text { Branches } \\
\text { and stems }\end{array}$ & 30 & $\begin{array}{l}\text { Parasitic on scale insect } \\
\text { only }\end{array}$ \\
\hline $\begin{array}{l}\text { Stereum (Haematostereum) } \\
\text { sanguinolentum }\end{array}$ & Rot & Native & $\begin{array}{l}\text { Usually } \\
\text { conifers }\end{array}$ & Woody parts & 2 & \\
\hline Sydowia polyspora & $\begin{array}{l}\text { Secondary } \\
\text { fungus }\end{array}$ & Native & Conifers & $\begin{array}{l}\text { Twigs and } \\
\text { shoots }\end{array}$ & 2 & $\begin{array}{l}\text { Secondary after other } \\
\text { injury }\end{array}$ \\
\hline Tulasnella fuscoviolacea & Rot & Native & Usually conifers & Woody parts & 3 & \\
\hline Tympanis hypopodia & $\begin{array}{l}\text { Canker - } \\
\text { secondary }\end{array}$ & Native & Conifers & Woody parts & 4 & \\
\hline Valsa pini & $\begin{array}{l}\text { Cytospora } \\
\text { canker }\end{array}$ & Native & Conifers & Woody parts & 2 & \\
\hline
\end{tabular}

Total Records

$871^{\mathrm{a}}$

aincludes all negative records, all records not determined to species and all collections where no causal organism could be identified.

fungus does not actually attack the tree. The fungus parasitizes a tiny scale insect that feeds on eastern white pine by inserting its feeding tube into the sapstream of the tree. The fungus is symbiotic with the scale insect; the fungus takes nutrition from some of the parasitized scale insects while providing shelter for other healthy scales in the colony.

B. There are 22 records for the needle cast, Lophodermium pinastri (Schrad.:Fr.) Chev. on eastern white pine nursery stock. Minter (1981) issues the following caution: "Most literature about Lophodermium on pines purports to concern this species but usually in fact concerns other species, or a mixture of species." This disease can be controlled in the nursery.

C. There are 13 records for "Shoestring root rot" or "Armillaria root rot" (called Armillaria mellea in the NFHDB).
What was called "Armillaria mellea" is actually a group of very similar and closely related species that occur on both deciduous and coniferous trees throughout North America. In recent years, the commonest species attacking conifers in Atlantic Canada was called "Armillaria ostoyae." According to Burdsall and Volk (2008), the valid name for Armillaria ostoyae (Romagnesi) Herink is actually Armillaria solidipes Peck so it is likely that A. solidipes is the name that should be applied to all of the "Armillaria mellea" records from Atlantic Canada in the NFHDB.

D. There are 12 reports of Lachnellula agassizii (Berk. \& M.A. Curtis) Dennis, "a bark fungus" that occurs on patches of dead conifer bark on eastern white pine and other conifers. Typically, it is present on trees that are dead or dying and declining due to attack by insects or diseases. 
E. As expected, there are records for various species of needle cast fungi including: Bifusella linearis (Peck) Höhn., Lophodermium nitens Darker and Meloderma desmazierii (Duby) Darker. These fungi are reported occasionally, but rarely cause significant problems.

\section{Conclusion}

With the notable exception of white pine blister rust, the fungi reported on eastern white pine from the Atlantic provinces are of native origin and of limited importance to the eastern white pine resource.

Even after a century since its introduction, the white pine blister rust remains the most widespread and significant constraint to the successful growth and management of eastern white pine in the Atlantic provinces.

\section{Acknowledgments}

The author extends sincere thanks for technical assistance to Mr. Sava Barudzija, System and Database Administrator for the National Forest Health Database at the Atlantic Forestry Centre. In addition, the author extends his thanks to the reviewers for suggestions that have improved the manuscript.

\section{References}

Burdsall, H.H., Jr. and T. J. Volk. 2008. Armillaria solidipes, an older name for the fungus called Armillaria ostoyae. N. Amer. Fungi 3(7): 261-267. doi: 10.2509/naf2008.003.00717.

Gourley, C.O. 1983. An annotated index of the fungi of Nova Scotia. Proc. N.S. Inst. Sci. 32: 75-293.

Harrison, K.J., J.E. Hurley, G.R. Warren and G. Laflamme. 2000. Expansion of the European race of Gremmeniella abietina in Newfoundland, Canada. Plant Dis. 84: 202.
Hausner, G., M. Iranpour, J.-J. Kim, C. Breuil, C.N. Davis, E.A. Gibb, J. Reid, P.C. Loewen and A.A. Hopkin. 2005. Fungi vectored by the introduced bark beetle Tomicus piniperda in Ontario, Canada, and comments of the taxonomy of Leptographium lundbergii, Leptographium terebrantis, Leptographium truncatum and Leptographium wingfieldii. Can. J. Bot. 83: 1222-1237.

Hodges, C.S. 1985. Diseases of eastern white pine. In Funk, D.T. (compl.) 1986. Eastern white pine: today and tomorrow. Symposium Proceedings pp. 93-98. USDA Forest Service General Technical Report WO-51. 124 p.

Hurley, J.E., K.J. Harrison and A.W. MacKay. 2000. Status of European larch canker, European race of scleroderris canker, butternut canker and Dutch elm disease in Atlantic Canada 1999. Can. Plant Dis. Sur. 80: 141-143.

Jacobs, K. and M.J. Wingfield. 2001. Leptographium Species: Tree Pathogens, Insect Associates and Agents of Blue-Stain. APS Press, St. Paul, Minnesota. 207 p.

Laflamme, G., A.A. Hopkin and K.J. Harrison. 1998. Status of the European race of Scleroderris canker in Canada. For. Chron. 74(4): 561-566.

Magasi, L.P. 1988. Forest pest conditions in the Maritimes 1987. Natural Resources Canada, Canadian Forestry Service - Atlantic Forestry Centre Information Report M-X-166. Fredericton, NB.

Minter, D.W. 1981. Lophodermium on pines. Mycological Papers, No. 147. Commonwealth Mycological Institute, Kew, Surrey, England. $72 \mathrm{p}$.

Sinclair, W.A. and H.H. Lyon. 2005. Diseases of Trees and Shrubs, $2^{\text {nd }}$ Edition. Comstock Publishing Associates, a division of Cornell University Press, Ithaca, NY. 660 p.

Sommers $[s i c]$, J. 1880. Nova Scotian Fungi. Proc. Trans. N.S. Inst. Sci. 5: 188-192. 